\title{
Genotoxic Maillard byproducts in current phytopharmaceutical preparations of Echinodorus grandiflorus
}

\author{
ELISANGELA C. LIMA-DELLAMORA ${ }^{1,2}$, KASSIA C.V. WALDHELM ${ }^{3}$, ADRIANA M. ALVES ${ }^{4}$, \\ CLAUDIA A.S. LAGE ${ }^{3,4}$, ALVARO A.C. LEITÃ ${ }^{4}$ and RICARDO M. KUSTER ${ }^{1,3}$ \\ ${ }^{1}$ Programa de Biotecnologia Vegetal, Universidade Federal do Rio de Janeiro, \\ Avenida Carlos Chagas Filho, 373, Cidade Universitária, 21941-902 Rio de Janeiro, RJ, Brasil \\ ${ }^{2}$ Faculdade de Farmácia, Universidade Federal do Rio de Janeiro, \\ Avenida Carlos Chagas Filho, 373, Cidade Universitária, 21941-902 Rio de Janeiro, RJ, Brasil \\ ${ }^{3}$ Instituto de Pesquisas de Produtos Naturais, Universidade Federal do Rio de Janeiro, \\ Avenida Carlos Chagas Filho, 373, Cidade Universitária, 21941-902 Rio de Janeiro, RJ, Brasil \\ ${ }^{4}$ Instituto de Biofísica Carlos Chagas Filho, Universidade Federal do Rio de Janeiro, \\ Avenida Carlos Chagas Filho, 373, Cidade Universitária, 21941-902 Rio de Janeiro, RJ, Brasil
}

Manuscript received on February 20, 2013; accepted for publication on January 17, 2014

\begin{abstract}
Extracts of Echinodorus grandiflorus obtained from dried leaves by three different techniques were evaluated by bacterial lysogenic induction assay (Inductest) in relation to their genotoxic properties. Before being added to test cultures, extracts were sterilized either by steam sterilization or ultraviolet light. Only the extracts prepared by infusion and steam sterilized have shown genotoxic activity. The phytochemical analysis revealed the presence of the flavonoids isovitexin, isoorientin, swertisin and swertiajaponin, isolated from a genotoxic fraction. They were assayed separately and tested negative in the Inductest protocol. The development of browning color and sweet smell in extracts submitted to heat, prompted further chemical analysis in search for Maillard's reaction precursors. Several aminoacids and reducing sugars were cast in the extract. The presence of characteristic Maillard's melanoidins products was determined by spectrophotometry in the visible region and the inhibition of this reaction was observed when its characteristic inhibitor, sodium bisulfite, was added prior to heating. Remarkably, this is the first paper reporting on the appearance of such compounds in a phytomedicine preparation under a current phytopharmaceutical procedure. The genotoxic activity of such heat-prepared infusions imply in some risk of developing degenerative diseases for patients in long-term, uncontrolled use of such phytomedicines.
\end{abstract}

Key words: Echinodorus grandiflorus, genotoxicity, Maillard's Reaction, flavonoids.

\section{INTRODUCTION}

Echinodorus grandiflorus species belong to a worldwide spread family Alismataceae. It is popularly known as chapéu de couro in Brazil, with a strong diuretic effect attributed to infusions made

Correspondence to: Elisangela da Costa Lima-Dellamora E-mail: elisangela@pharma.ufrj.br /

lima.dellamora@gmail.com from its leaves. Industrially, it is one of the main ingredients for popular soft drinks, being cultivated for this purpose in the Rio de Janeiro and Minas Gerais regions. Antinociceptive, antiinflamatory and hypocholesterolemic activities were also reported to occur in addition to the diuretic one (Cardoso et al. 2003). A recent in vitro study suggests that $E$. grandiflorus aqueous extracts may 
modulate pulmonary allergic responses (Brugiolo et al. 2011). Exposure of renal cells to Echinodorus extracts however, have induced genotoxic effects (Lopes et al. 2000), corroborated by results of increased mutagenic and lysogenic induction in bacterial cells (Vidal et al. 2010).

Phytochemical evaluation of extracts made from leaves has led to the identification of cembrane and clerodane-type diterpenoids, sesquiterpenes and flavonoids (Schnitzler et al. 2007, Costa et al. 1999, Tanaka et al. 1997, Manns and Hartmann 1993). Maillard's products, those originated from the reaction between aminoacids and reducing sugars upon heating, are well known mutagenic compounds and their formation in food products is kept to a minimum to prevent loss of quality and nutritional properties (Powrie et al. 1986). Inversely to Food Chemistry, little effort has been made in the field of medicinal plant chemistry to identify Maillard's reaction products in phytomedicines and popular plant preparations. The genotoxic and mutagenic effects detected so far, deriving from exposure to such preparation, might find their cause on the presence of such Maillard's products due to heat sterilization procedures.

In this paper we report the formation of melanoidin, a known mutagenic compound, in infusions made of Echinodorus grandiflorus and test the influence of other sterilization processes and pharmaceutical preparations on the genotoxic activity of the extract.

\section{MATERIALS AND METHODS}

PLANT

Echinodorus grandiflorus were kindly provided by a local pharmaceutical industry (Laboratório Simões Ltd., Rio de Janeiro, Brazil) after being collected (Nova Friburgo, Rio de Janeiro, Brazil) in April 2004 and identified by Dr. Yara Lucia Oliveira de Britto from the Rio de Janeiro Botanical Garden (Brazil), where an exsiccate sample is deposited.
PREPARATION OF EXTRACTS AND SOLUTIONS

Aqueous extract: $200 \mathrm{~g}$ dried leaves were sonicated in $1000 \mathrm{~mL}$ water during 10 minutes. After this procedure, the extract was filtered in paper and the initial volume restored with distilled water. Ethanol extract: $400 \mathrm{~g}$ dried leaves were immersed in 2000 $\mathrm{mL} 96^{\circ}$ ethanol and macerated during 24 hours. After this procedure, the extract was filtered in paper and the initial volume restored with $96^{\circ}$ ethanol. Infusion: $100 \mathrm{~mL}$ boiling water was added to $10 \mathrm{~g}$ dried leaves in a becker and permitted to stand there until cooling. After this procedure, the extract was filtered in paper and the initial volume restored with distilled water. Decoction: $10 \mathrm{~g}$ dried leaves and $100 \mathrm{~mL}$ water were added together in a Becker for boiling for 60 and 90 minutes. After boiling, extract was filtered in paper and the initial volume replenished with distilled water. Sterilization: Infusions, aqueous extracts and ethanol extracts were sterilized through exposition to germicidal (254 nm) ultraviolet light (UV) at a dose rate of 2 Joules $/ \mathrm{m}^{2} / \mathrm{s}$ for 15 minutes $\left(1800 \mathrm{~J} / \mathrm{m}^{2}\right)$, in addition the traditional steam-sterilization process.

AqueOUs SOlutions of SUGARS AND AMINOACIDS

Control mixtures of glucose with or without aminoacids were prepared as follows: Solution A: glucose $(10 \mathrm{~g} / 100 \mathrm{~mL})$; Solution B: glucose $(10 \mathrm{~g} / 100 \mathrm{~mL})+200 \mathrm{mg}$ L-tryptophan; Solution C: glucose $(10 \mathrm{~g} / 100 \mathrm{~mL})+200 \mathrm{mg}$ L-isoleucine +200 mg L-alanine $+200 \mathrm{mg}$ L-methionine $+200 \mathrm{mg}$ L-threonine $+200 \mathrm{mg}$ L-serine $+200 \mathrm{mg}$ L-leucine $+200 \mathrm{mg}$ L-valine.

INFUSION AND ETHANOL EXTRACT: FRACTIONATION AND PURIFICATION

The infusion $(900 \mathrm{~mL})$ was partitioned with hexane and ethyl acetate successively. The aqueous residue was lyophilized and the resulting solid was solubilized in methanol:water $(1: 1)$ to be fractionated by column chromatography $(50 \times 2 \mathrm{~cm})$ on XAD-2 (Sigma). Elution with 
water yielded 7 fractions named F1, F2, F3, F4, F5, F6 and F7, of which the first four were considered of good yield. The ethanol extract was partitioned between several solvents and water. One of the partitions, the ethyl acetate one, was chromatographed on Sephadex LH-20 (Pharmacia) column $(60 \times 4 \mathrm{~cm})$ and eluted with methanol:water 1:1 (47 fractions). That fraction containing flavonoids (named FF) was chromatographed on Sephadex LH-20 (Pharmacia) column (50 x $2.5 \mathrm{~cm}$ ) under the same conditions (39 fractions) above, until complete purification of the four compounds. These pure compounds were developed after spraying the TLC chromatogram (stationary phase: silica gel; mobile phase: ethyl acetate/methanol/ water/acetic acid 80:10:5:5 $\mathrm{v} / \mathrm{v}$ ) with NP/PEG, a characteristic reagent for flavonoid identification: isovitexin ( $\mathrm{Rf}$ value of 0.80 ), isoorientin ( $\mathrm{Rf}$ value of 0.50 ), swertisin ( $\mathrm{Rf}$ value of 0.90 ) and swertiajaponin ( $\mathrm{Rf}$ value of $0.65)$. Thus, the compounds were analyzed by ${ }^{1} \mathrm{H}$, ${ }^{13} \mathrm{C}-\mathrm{NMR}, \mathrm{HMQC}$ and HMBC techniques and the data were compared with literature (Cheng et al. 2000, Kumarasamy et al. 2004).

\section{CHARACTERIZATION OF THE FLAVONOIDS}

Isovitexin: ${ }^{1} \mathrm{H}-\mathrm{NMR}\left(\mathrm{DMSO}_{\mathrm{d}} \mathrm{d}_{6}\right)-\mathrm{H}-3$ (s, 6.70 ppm); H-2' and H-6' (d, J = 8.0 Hz, 7.89); H-3' and H-5' (d, J = 8.0, 6.91); H-8 ( s, 6.41); H-1" (d, J = 7.5, 4.59); 5 - OH (s, 13.5) $/{ }^{13} \mathrm{C}-\mathrm{NMR}$ (DMSO-d 6 ) - C-2 (163.3), C-3 (102.6), C-4 (181.7), C-5 (160.8), C-6 (109.3), C-7 (163.5), C-8 (94.1), C-9 (156.6), C-10 (102.5), C-1' (121.0), C-2'and C-6' (128.5), C-3' and C-5' (116.2), C-4' (161.7), C-1" (73.3), C-2" (70.7), C-3" (79.2), C-4" (70.2), C-5" (81.6), C-6" (61.6). Isoorientin ${ }^{1} \mathrm{H}-\mathrm{NMR}$ (DMSO-d $\left.\mathrm{d}_{6}\right)-\mathrm{H}-3$ ( $\mathrm{s}, 6.67$ ppm); H-2' (d, J = 2.0 Hz, 7.42); H-5' (d, J = 8.0, 6.90); H-6' (dd, J = 8.0 and 2.0, 7.41); H-8 (s, 6.51); H-1" (d, $\mathrm{J}=7.5,4.60) ; 5-\mathrm{OH}(\mathrm{s}, 13.5) /{ }^{13} \mathrm{C}-\mathrm{NMR}\left(\right.$ DMSO-d $\left._{6}\right)$ - C-2 (163.7), C-3 (102.9), C-4 (182.0), C-5 (160.8), C-6 (108.9), C-7 (163.4), C-8 (93.6), C-9 (156.3), C-10 (103.5), C-1' (121.5), C-2'(113.4), C-3' (145.8),
C-4' (149.8), C-5' (116.2), C-6' (119.1), C-1" (73.2), C-2" (70.7), C-3" (79.0), C-4" (70.3), C-5" (81.7), C-6" (61.6). Swertisin ${ }^{1} \mathrm{H}-\mathrm{NMR}$ (DMSO-d $\left.\mathrm{d}_{6}\right)-\mathrm{H}-3$ (s, 6.83 ppm); H-2' and H-6' (d, J = 8.0 Hz, 7.96); H-3' and $\mathrm{H}^{-5}$ ' (d, J = 8.0, 6.93); H-8 ( s, 6.85); H-1" (d, J = 7.5, 4.58); 5-OH (s, 13.5); 7- $\mathrm{OCH}_{3}$ (3.8). ${ }^{13} \mathrm{C}-\mathrm{NMR}$ (DMSO-d 6 ) - C-2 (164.1), C-3 (103.2), C-4 (182.2), C-5 (160.0), C-6 (110.1), C-7 (165.4), C-8 (90.5), C-9 (157.2), C-10 (104.5), C-1' (121.2), C-2'and C-6' (129.0), C-3' and C-5' (116.5), C-4' (162.0), C-1" (70.7), C-2" (72.6), C-3" (78.9), C-4" (69.5), C-5" (81.7), C-6" (61.5), 7-OCH3 (56,3). Swertiajaponin ${ }^{1} \mathrm{H}-\mathrm{NMR}$ (DMSO-d ${ }_{6}$ - H-3 (s, $\left.6.71 \mathrm{ppm}\right) ; \mathrm{H}-2^{\prime}$ (d, $\mathrm{J}=2.0 \mathrm{~Hz}, 7.44)$; H-5' (d, J = 8.0, 6.87); H-6' (dd, J $=8.0$ and 2.0, 7.45); H-8 ( s, 6.78); H-1" (d, J = 7.5, 4.60); 5 - OH (s, 13.5); 7-OCH 3 (3.9) $/{ }^{13} \mathrm{C}-\mathrm{NMR}$ (DMSO-d 6 ) - C-2 (164.2), C-3 (103.2), C-4 (182.4), C-5 (160.7), C-6 (110.1), C-7 (164.2), C-8 (90.5), C-9 (157.3), C-10 (104.5), C-1' (121.2), C-2'(113.7), C-3' (146.5), C-4' (151.2), C-5' (116.4), C-6' (119.1), C-1" (72.4), C-2" (70.7), C-3" (78.8), C-4" (69.5), C-5" (81.7), C-6" (61.5), 7-OCH3 (56.1).

IDENTIFICATION OF AMINOACIDS AND SUGARS

The thin layer chromatography on silica gel 60 F254 (Merck) with authentic standards (SigmaAldrich) was run for identification of aminoacids and sugars. Pure aminoacids were run together with samples, with a solvent system consisting of: ethyl acetate : water : ethanol : acetic acid (9:2:2:2) and ninhydrin as the developing spraying reagent. Sugars were chromatographed with a solvent system consisting of: butanol : water : ethanol : acetic acid (4:1:1:0.5) and orcinol/sulphuric acid as the developing spraying reagent.

\section{BACTERIAL MEDIA}

Bacterial cells were grown overnight in a shaking incubator at $37^{\circ} \mathrm{C}$, in LB medium (Miller 1992). A start inoculum of the lysogenic strain was taken from this culture and cells were grown in the same medium until their exponential phase $\left(10^{8}\right.$ cells $\left./ \mathrm{mL}\right)$. 
E. coli bacterial survival and induced infective centers (see below) were scored by plating samples in LB medium and LB medium containing $20 \mathrm{ug} /$ $\mathrm{mL}$ ampicilin (LB-amp), respectively. Both media were solidified with $1.5 \%$ Difco bacto agar.

\section{LYSOGENIC INDUCTION ASSAY}

The E. coli $\mathrm{B} / \mathrm{r}$ strains WP2s $(\lambda)(\mathrm{WP} 2 u v r \mathrm{~A}(\lambda)$ trp E) and RJF013 (B/r SR714 $\left.u v r \mathrm{D} 3 \operatorname{trp\mathrm {E}} \mathrm{Amp}^{\mathrm{R}}\right)$ were used in the lysogenic induction assays, and the protocol was similar to the quantitative Inductest developed by Moreau et al. (1976). Each experimental determination was performed in duplicate, and the results represent the average of at least three experiments. Test preparations $(150 \mathrm{uL})$ were incubated at $37^{\circ} \mathrm{C}$ for $20 \mathrm{~min}$, in the dark, with $100 \mathrm{uL}$ of lysogenic culture, diluted to $10^{4}$ cells $/ \mathrm{mL}$. Then, $0.3 \mathrm{ml}$ of an overnight culture of RJF013 strain and $0.25 \mathrm{~mL}$ molten soft agar were added and the mixture was poured onto LB-amp plates. Plates were incubated overnight at $37^{\circ} \mathrm{C}$, and plaques were scored afterwards. The lysogenic induction was determined as the number of infective centers per $10^{4}$ cells. As a negative control, $150 \mathrm{uL}$ pure water was added to the cultures to measure the spontaneous induction that averaged $6.8 \pm 2.8$ infective centers per $10^{4}$ lysogenic cells. As a positive control a single UV-C radiation dose $\left(2 \mathrm{~J} / \mathrm{m}^{2}\right)$ was given to cultures and the induced infective centers were scored, with an average $645.8 \pm 65.4$ infective centers per $10^{4}$ lysogenic cells. Bacterial survival ranged between 90 and $100 \%$ under these conditions.

\section{SODIUM BISULFITE ADDITION AND SPECTROPHOTOMETRY}

Four systems (A1, B1, A2, B2) were prepared by mixing $20 \mathrm{~mL}$ of E. grandiflorus infusions in $50 \mathrm{ml}$ hydrolysis tubes with addition of $20 \mathrm{mg}$ sodium bisulfite only in tubes B1 and B2. The tubes were placed in a boiling water bath for 60 minutes (A1 e B1) and 90 minutes (A2 e B2). After heating, the tubes were centrifuged at $10000 \mathrm{rpm}$ for 8 minutes
(Fogliano et al. 1999). Pellets were discarded and UV-visible spectra of the supernatants were recorded.

\section{Statistical ANALYSES}

The results are given as average \pm standard deviation. Multiple comparisons were made by analysis of variance (ANOVA).

\section{RESULTS AND DISCUSSION}

Echinodorus grandiflorus preparations were tested for genotoxic activity by means of Escherichia coli lysogenic induction (Inductest) assay. Prophageinduced bacterial lysis ensues whenever a genotoxic agent targets the bacterial genome. E. grandiflorus extracts prepared under different forms were subjected to the Inductest protocol. Two procedures of sample sterilization were used, steam and UV sterilization. Only the extract prepared by infusion and steam sterilization resulted positive in the Inductest assay (Table I).

Additionaly, increased browning and sweetened smell were observed to develop in this steam sterilized extract. In search for the compounds responsible for the observed effects, genotoxic activity of the major fractions (F1, F2, F3 and F4) was evaluated by inductest protocol (Table II).

The genotoxic activity remained in the more polar fractions. The ethyl acetate partition was not active in the Inductest at the assayed concentration $(5 \mathrm{mg} /$ plate). However, the four flavonoids identified (isovitexin, isoorientin, swertisin and swertiajaponin) alone were genotoxic at the tested concentration (5 mg/plate) (Figure 1). Although fraction FF had not been active in the Inductest, flavonoids were its main constituents. As this class of compounds can be mutagenic, as described by several researchers, they had to be purified in order to verify their genotoxicity.

Flavonoids are well known antioxidant, anticarcinogenic and antimutagenic natural compounds. However, if present in higher concentrations, these 
TABLE I

Bacterial Inductest results after exposure to Echinodorus grandiflorus extracts prepared under different conditions.

\begin{tabular}{|c|c|c|c|c|}
\hline Sample & Volume & $\begin{array}{c}\text { Sterilization } \\
\text { method }\end{array}$ & $\begin{array}{c}\text { Bacterial } \\
\text { survival }\left(\mathrm{N} / \mathbf{N}_{0}\right)\end{array}$ & $\begin{array}{c}\text { Infective centers } \\
\text { per } 10^{4} \text { cells }^{(1)}\end{array}$ \\
\hline $\begin{array}{c}\text { Aqueous } \\
\text { Extract (AE) }\end{array}$ & $150 \mathrm{uL}^{(2)}$ & $\mathrm{SS}^{(3)}$ & $1 \pm 0.07$ & $12.0 \pm 2.3$ \\
\hline $\mathrm{AE}$ & $150 \mathrm{uL}$ & $\mathrm{UVS}^{(4)}\left(1800 \mathrm{~J} / \mathrm{m}^{2}\right)$ & $1 \pm 0.06$ & $8.2 \pm 1.2$ \\
\hline $\begin{array}{c}\text { Ethanolic } \\
\text { Extract (EE) }\end{array}$ & $150 \mathrm{uL}$ & $\mathrm{SS}$ & $1 \pm 0.09$ & $10.6 \pm 2.7$ \\
\hline $\mathrm{EE}$ & $150 \mathrm{uL}$ & $\operatorname{UVS}\left(1800 \mathrm{~J} / \mathrm{m}^{2}\right)$ & $1 \pm 0.09$ & $6.6 \pm 2.3$ \\
\hline Infusion (IE) & $150 \mathrm{uL}$ & SS & $0.93 \pm 0.05$ & $979.6 \pm 149.7$ \\
\hline IE & $150 \mathrm{uL}$ & UVS $\left(1800 \mathrm{~J} / \mathrm{m}^{2}\right)$ & $0.93 \pm 0.08$ & $13.0 \pm 1.1$ \\
\hline \multicolumn{5}{|c|}{$\begin{array}{l}{ }^{(1)} \text { Statistically different means }(p \text {-value }<0.0001) \text { (two } \\
\text { posttests). } \\
\text { (2) microliter. } \\
{ }^{(3)} \mathrm{SS}-\text { steam sterilization }-120^{\circ} \mathrm{C} \text { for } 20 \text { minutes. } \\
{ }^{(4)} \mathrm{UVS}-\text { ultraviolet sterilization }\left(2 \mathrm{~J} / \mathrm{m}^{2} / \mathrm{s}\right) \text {. }\end{array}$} \\
\hline
\end{tabular}

TABLE II

Bacterial Inductest results after exposure to the fractions obtained from infused extracts.

\begin{tabular}{|c|c|c|c|}
\hline Sample & Volume & $\begin{array}{c}\text { Bacterial } \\
\text { survival }\left(\mathbf{N} / \mathbf{N}_{0}\right)\end{array}$ & $\begin{array}{l}\text { Infective centers } \\
\text { per } 10^{4} \text { cells }^{(1)}\end{array}$ \\
\hline Ethyl Acetate Partition & $5 \mathrm{mg}^{(2)} /$ plate & $1.0 \pm 0.09$ & $11.3 \pm 4.2$ \\
\hline $\begin{array}{l}\text { Aqueous Residue } \\
\text { Lyophilized }\end{array}$ & $5 \mathrm{mg} /$ plate & $0.93 \pm 0.05$ & $392.3 \pm 43.4$ \\
\hline F1 & $5 \mathrm{mg} /$ plate & $0.91 \pm 0.05$ & $285.8 \pm 90.7$ \\
\hline F2 & $5 \mathrm{mg} /$ plate & $0.88 \pm 0.08$ & $146.0 \pm 24.8$ \\
\hline F3 & $5 \mathrm{mg} /$ plate & $0.87 \pm 0.10$ & $17.0 \pm 4.1$ \\
\hline F4 & $5 \mathrm{mg} /$ plate & $0.96 \pm 0.05$ & $20.0 \pm 4.1$ \\
\hline
\end{tabular}

${ }^{(1)}$ Statistically different means ( $p$-value $<0.0001$ ) (one-way ANOVA, followed by Tukey's multiple comparision test). ${ }^{(2)}$ milligram.

substances can be pro-oxidants and elicit mutagenic responses (Rietjens et al. 2005). Noteworthy is that the identified C-glycosylflavonoids are well characterized antioxidants and xanthine oxidase inhibitors (Pham et al. 2013). This can explain the popular use of the plant for treatment of diseases of the genitourinary tract.

During the chemical fractionation of steam sterilized infused extract, an aromatic smell and browning aspect developed, and compounds appeared to remain in fractions F1 and F2 (Figure 1). A Maillard's (Maillard 1912) reaction was then envisaged to explain the observed genotoxic effects and further investigated. First of all, the presence of reducing sugars and aminoacid precursors in the infusion was investigated by TLC. Aspartic acid, threonine, serine, valine, methionine, alanine, glutamic acid, phenylalanine, proline, arginine, tyrosine, leucine, glycine, lysine and cysteine were the identified aminoacids and galactose, glucose, maltose and lactose, the reducing sugars. Thus, control solutions A, $10 \%$ glucose, B, 10\% glucose plus $0.5 \%$ tryptophan, and C, $10 \%$ glucose plus an aminoacid mixture (according to description provided in Materials and Methods) were prepared 


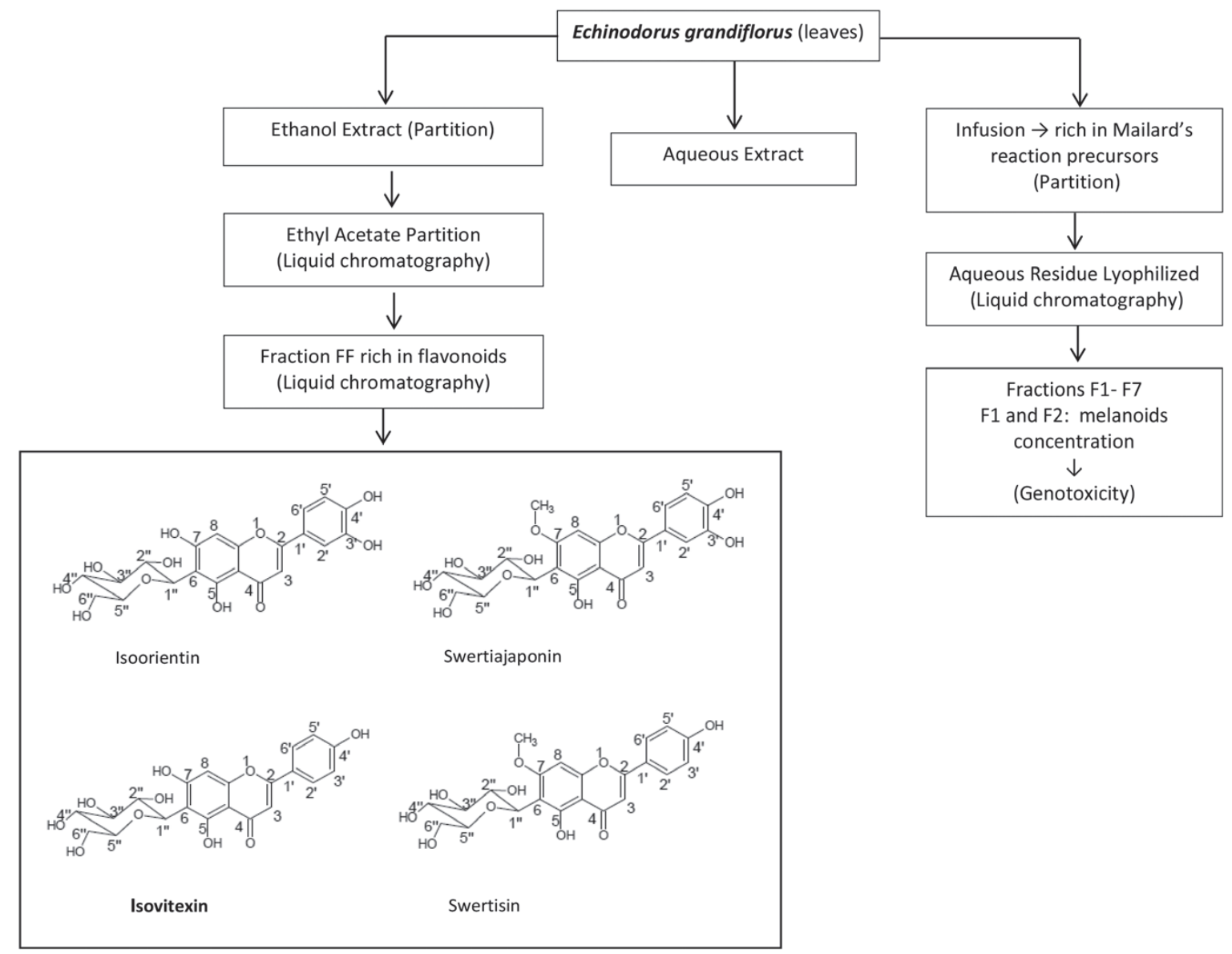

Figure 1 - Synthesis of principal results.

TABLE III

Smell releasing, browning and absorbance inspection as evidence for development of Maillard's Reaction.

\begin{tabular}{|c|c|c|c|c|c|}
\hline Sample & $\begin{array}{c}\text { Solution } \\
\text { organoleptic } \\
\text { properties }\end{array}$ & $\begin{array}{c}\text { Absorbance }(420 \mathrm{~nm}) \\
\text { before steam sterilization }\end{array}$ & $\begin{array}{l}\text { Solution appearance } \\
\text { after steam sterilization }\end{array}$ & $\begin{array}{l}\text { Absorbance }(420 \mathrm{~nm}) \\
\text { after steam sterilization }\end{array}$ & $p$-value $e^{(1)}$ \\
\hline Solution A & $\begin{array}{l}\text { Colorless and } \\
\text { odorless }\end{array}$ & 0 & $\begin{array}{l}\text { Yellowish and sweetened } \\
\text { smell }\end{array}$ & 0 & - \\
\hline Solution B & $\begin{array}{l}\text { Colorless and } \\
\text { odorless }\end{array}$ & $0.043 \pm 0.003$ & $\begin{array}{l}\text { Yellowish and sweetened } \\
\text { smell }\end{array}$ & $0.063 \pm 0.001$ & $<0.0001$ \\
\hline Solution C & $\begin{array}{l}\text { Colorless and } \\
\text { odorless }\end{array}$ & $0.0134 \pm 0.001$ & $\begin{array}{l}\text { Yellowish and sweetened } \\
\text { smell }\end{array}$ & $0.0178 \pm 0.002$ & $<0.0001$ \\
\hline
\end{tabular}

${ }^{(1)}$ unpaired Student's t-test comparing absorbance mean before and after stem sterilization for each solution.

and steam sterilized. As expected, aromatic smell and browning developed in solutions $\mathrm{B}$ and $\mathrm{C}$ (absorbance at $420 \mathrm{~nm}$, see Table III).

Changes in organoleptic properties of solutions $\mathrm{B}$ and $\mathrm{C}$ were suggestive of the presence of Maillard's products. The Maillard's characteristic browning color is due to melanoidin formation in heated preparations. Recently, products of Maillard's reaction have been related to enhanced mutagenicity, connected with increased accumulation of reactive oxygen species and 
DNA damage (Janzowski et al. 2000, Monnier 2003, Coca et al. 2004, Kwak et al. 2005). Literature surveys (Friedman 1996, Namiki 1988) about browning appearance in preparations subjected to heating processes indicated that it develops proportionally to aminoacid concentration and reduced capacity of the reactant sugars. Martins and Van Boekel (2003) have suggested a random polymerization of heat-degradation products of sugars with amino groups, like those present in aminoacids. The precise mechanism of melanoidin formation (brown color) and its structure are not yet fully understood. Time, temperature, $\mathrm{pH}$ and water quantity are determinant factors influencing the extent of the reaction (Martins and Van Boekel 2003, Van Boekel 2006).

Both steam sterilized infusions and UV sterilized decoctions of Echinodorus grandiflorus were assayed by the Inductest protocol. Lysogenic

TABLE IV

Lysogenic activity, browning formation of Echinodorus grandiflorus preparations and inhibition of Maillard's Reaction by sodium bisulfite.

\begin{tabular}{|c|c|c|c|c|}
\hline Sample & $\begin{array}{l}\text { Volume/ } \\
\text { Dose }\end{array}$ & $\begin{array}{c}\text { Bacterial } \\
\text { survival }\left(\mathrm{N} / \mathbf{N}_{0}\right)\end{array}$ & $\begin{array}{c}\text { Infective } \\
\text { centers }\left(10^{4}\right)^{(1)}\end{array}$ & $\begin{array}{l}\text { Browning - } \\
\text { absorbance at } 420 \mathrm{~nm}^{(2)}\end{array}$ \\
\hline Infusion & $150 \mathrm{uL}$ & $1 \pm 0.8$ & $23.0 \pm 7.1$ & $0.4075 \pm 0.01$ \\
\hline $\begin{array}{l}\text { Steam Sterilized } \\
\text { Infusion }\end{array}$ & $150 \mathrm{uL}$ & $0.68 \pm 0.22$ & $898.0 \pm 82.4$ & $0.5753 \pm 0.012$ \\
\hline Decoction for $60 \mathrm{~min}$ & $150 \mathrm{uL}$ & $0.90 \pm 0.17$ & $272.8 \pm 36.8$ & $0.5131 \pm 0.011$ \\
\hline Decoction for $90 \mathrm{~min}$ & $150 \mathrm{uL}$ & $0.90 \pm 0.2$ & $188 \pm 13.9$ & $0.4695 \pm 0.01$ \\
\hline $\begin{array}{c}\text { Decoction for } 60 \mathrm{~min}+ \\
\mathrm{NaHSO}_{3} 0.1 \%\end{array}$ & $150 \mathrm{uL}$ & - & - & $0.4291 \pm 0.015$ \\
\hline $\begin{array}{c}\text { Decoction for } 90 \mathrm{~min}+ \\
\mathrm{NaHSO}_{3} 0.1 \%\end{array}$ & $150 \mathrm{uL}$ & - & - & $0.4261 \pm 0.011$ \\
\hline
\end{tabular}

induction was shown to increase after exposure of test bacterial cultures to decocts when compared to that observed for infusions preparations (Table IV).

Lysogenic induction was seen to increase only when samples were steam sterilized $\left(120^{\circ} \mathrm{C}, 20 \mathrm{~min}\right)$. However, the decoction - an extractive technique involving longer boiling times and contact among reactant compounds than infusion-prepared ones caused browning formation (as measured by absorption at $420 \mathrm{~nm}$ ) and genotoxicity. Melanoidin formation depends on strict reaction kinetics. It appears steeply with increasing times of decoction (Cuzzoni et al. 1988). Nevertheless, Baisier and Labuza (1992) while analyzing melanoidin formation by fluorescence spectroscopy found decay in melanoidin fluorescence whenever longer times were given for Maillard's reaction to occur. They suggested that degradation of melanoidin pigment could somehow explain the phenomenon. Accordingly, decoction for 60 min caused more melanoidin to form and lysogenic activity than that carried out for $90 \mathrm{~min}$ in this study.

Finally, Maillard's reaction was partially inhibited when decoction of Echinodorus grandiflorus leaves was prepared in the presence of $0.1 \%$ sodium bisulfite, a well-known inhibitor for that reaction. Sodium bisulfite caused $420 \mathrm{~nm}$ absorbance to drop in decocts, in comparison with control samples. In Table IV, a drop in $420 \mathrm{~nm}$ absorbance (0.4291) can be seen when preparations were boiled for $60 \mathrm{~min}$ in comparison with the absorbance value of 0.4954 found for decoction during $60 \mathrm{~min}$ without sodium bisulfite addition. The initial $420 \mathrm{~nm}$ absorbance of Echinodorus grandiflorus' infusion was 0.3774 .

Maillard's-induced melanoidins pigments responsible for browning color in foods are polymeric compounds of pyrrol and furan rings formed 
during more advanced stages of the reaction (Tressl et al. 1998). Remarkably, this is the first paper reporting in the appearance of such compounds in a phytomedicine. Mutagenic and genotoxic activities of those compounds were widely described (Kim et al. 1991, Powrie et al. 1981, Monnier 2003, Jägerstad and Skog 2005). Attention has to be paid if these compounds appear in phytomedicines.

\section{CONCLUSION}

Steam sterilization of infusion and decoction preparations of Echinodorus grandiflorus led to formation of Maillard's reaction products, as seen by the browning formation and the releasing of characteristic smell. Bio-guided fractionation by Inductest led to isolation of the flavonoids isovitexin, isoorientin, swertisin and swertiajaponin, which, in turn, were devoid of genotoxic effects when tested separately. Since Maillard's reaction precursors were casted in such aqueous fractions, i.e., aminoacids and reducing sugars, we have concluded that melanoidins, well-known mutagenic and genotoxic compounds can be formed in such preparations. The phythomedicines and other derived formulations need to be assessed in relation to melanoidin formation, as is widely verified in the food industry, to assure safeness for human consumption.

\section{RESUMO}

Extratos de Echinodorus grandiflorus, obtidos a partir de folhas secas por três técnicas diferentes, foram avaliados pelo ensaio de indução lisogênica bacteriana (Induteste), em relação às propriedades genotóxicas. As amostras foram previamente esterilizadas por vapor de água (autoclavação) ou luz ultravioleta. Somente os extratos preparados por infusão e esterilizados a vapor mostraram atividade genotóxica. A análise fitoquímica revelou a presença dos flavonóides isovitexina, isoorientina, swertisina e swertiajaponina. Isovitexina e isoorientina, isoladas de uma fração genotóxica, foram testadas separadamente e não apresentaram genotoxidade. $\mathrm{O}$ desenvolvimento de odor adocicado e escurecimento dos extratos submetidos ao calor motivaram a investigação quanto às substâncias precursoras da reação de Maillard no extrato. Ácidos aminados e açúcares redutores foram identificados e a presença de precursores da reação de Maillard no extrato foi confirmada por espectrofotometria no visível com a adição do inibidor bissulfito de sódio antes do aquecimento. Este é o primeiro relato de aparecimento de melanoidinas em uma técnica que pode ser usada para a preparação de fitoterápico. A atividade genotóxica de tais infusões preparadas ao calor implica em algum risco de desenvolvimento de doenças degenerativas com seu uso descontrolado e por longo prazo.

Palavras-chave: Echinodorus grandiflorus, genotoxidade, reação de Maillard, flavonóides.

\section{REFERENCES}

BAISIER WM AND LABUZA TP. 1992. Maillard browning kinetics in a liquid model system. J Agric Food Chem 40: 707-713.

BRUGiOLO AS ET AL. 2011. Effects of aqueous extract of Echinodorus grandiflorus on the immune response in ovalbumin-induced pulmonary allergy. Ann Allergy Asthma Immunol 106: 481-488.

CArdoso GLC, Pereira NA And Lainetti R. 2003. Avaliação das atividades antinociceptiva, antiinflamatória e diurética de chapéu de couro (Echinodorus grandiflorus, Cham. e Schl, Alismataceae). Rev Bras Farm 84: 5-7.

Cheng, G, Bai Y, Tao J, Tu G, Ma L, Liao N and Xu X. 2000. Flavonoids from Ziziphus jujuba Mill var. spinosa. Tetrahedron 56: 8915-8920.

COCA MM, GARCÍA T, GONZÁLEZ G, PEÑA M AND GARCÍA JA 2004. Study of coloured components formed in sugar beet processing. Food Chem 86: 421-433.

Costa M, TANAKa CMA, Imamura PM And Marsaioli AJ. 1999. Isolation and synthesis of a new clerodane from Echinodorus grandiflorus. Phytochemistry: 50: 117-122.

Cuzzoni MT, Stoppini G, Gazzani G And Mazza P. 1988. Influence of water activity and reaction temperature of ribose-lysine and glucose-lysine Maillard systems on mutagenicity, absorbance and content furfurals. Food Chem Toxicol 26: 815-822.

Fogliano V, Monti SM, Musella T, Randazzo G AND RITIENI A. 1999. Formation of coloured Maillard reaction products in a gluten-glucose model system. Food Chem 66: 293-299.

FRIEDMAN M. 1996. Food Browning and its prevention: an overwiew. J Agric Food Chem 44: 631-653.

JÄGERSTAD M AND SKOG K. 2005. Genotoxicity of heatprocessed foods. Mutat Res 574: 156-172. 
JANZOWSKI C, GLAAB V, SAMIMI E, SCHLATtER J AND EISENBRAND G. 2000. 5- Hydroxymethylfurfural: assessment of mutagenicity, DNA-damaging potencial and reactivity towards cellular glutathione. Food Chem Toxicol 38: 801-809.

KIM SB, KIM IS, YEUM DM AND PARK YH. 1991. Mutagenicity of Maillard reaction products from D-glucose-amino acid mixtures and possible roles of active oxygens in the mutagenicity. Mutat Res 254: 65-69.

Kumarasamy Y, Byres M, CoX PJ, Delazar A, Jaspars M, NAHAR L, SHOEB M AND SARKER SD. 2004. Isolation, structures elucidation, and biological activity of flavone 6-C-glycosides from Alliaria petiolata. Chem Nat Compd 40: 122-128.

KWAK EJ, LeE YS, Murata M AND Homma S. 2005. Effect of $\mathrm{pH}$ control on the imtermediates and melanoidins of nonenzymatic browning reaction. Lebensm. Wiss. U-Technol 38: 1-6.

LiU Z, Chao Z, LiU Y, Song Z AND Lu A. 2009. Maillard reaction involved in the steaming process of the root of Polygonum multiflorum. Planta Med 75: 84-88.

LiU Z, LiU Y, ChaO Z, Song Z, WANG C AND LU A. 2011. In vitro antioxidant activities of maillard reaction products produced in the steaming process of Polygonum multiflorum root. Nat Prod Commun 6: 55-58.

Lopes LC, Albano F, LARANJA GAT, AlVEs LM, MartinsE-Silva LF, Souza GP, Araujo IM, Nogueira-Neto JF, FElZENSWALB I AND KovAry K. 2000. Toxicological evaluation by in vitro and in vivo assays of an aqueous e extract prepared from Echinodorus macrophyllus leaves. Toxicol Lett 116: 189-198.

MAILlARD LC. 1912. Action des acides amines sur les sucres: formations des melanoidines par voie methodologique. C R Acad Sci 154: 66-68.

MANNS D AND HARTMANN R. 1993. Echinodol: a new cembrene derivative from Echinodorus grandiflorus. Planta Med 59: 465-466.

MARTINS SIFS AND VAN BoEKEL MAJS. 2003. Melanoidins extinction coefficient in the glucose/glycine Maillard reaction. Food Chem 83: 135-142.

MiLleR JH. 1992. A short course in bacterial genetics. Cold Spring Harbor Laboratory Press, Cold Spring Harbor New York, 876 p.
MONNIER VM. 2003. Intervention against the Maillard reaction in vivo. Arch Biochem Biophys 419: 1-15.

Moreau P, Bailone A And Devoret R. 1976. Prophage 1 induction in Escherichia coli $\mathrm{K} 12$ envA $u v r \mathrm{~B}$ : a highly sensitive test for potential carcinogens. Proc Natl Acad Sci 73: 3700-3704.

NAMIKI HE. 1988. Chemistry of Maillard reactions: recent studies on the browning reaction mechanism and the developments of anti-oxidants and mutagens. Adv Food Res 32: 115-184.

Pham AT, NGuyen C, Malterud KE, Diallo D And WANGENTEEN H. 2013. Bioactive Flavone-C-Glycosides of the african medicinal plant Biophytum umbraculum. Molecules 18: 10312-10319.

POWRIE WD, WU CH AND MOLUND VP. 1986. Browning reaction systems as sources of mutagens and antimutagens. Environ Health Perspect 67: 47-54.

Powrie WD, Wu CH, Rosin MP AND STICH HH. 1981. Clastogenic and mutagenic activities of Maillard reaction model systems. J Food Sci 46: 1433-1438.

RiETJENS IMCM, Boersma MG, VAN Der Woude $H$, JEURISSEN SMF, SCHUTTE ME AND ALINK GM. 2005. Flavonoids and alkenylbenzenes: mechanisms of mutagenic action and carcinogenic risk. Mutat Res 574: 124-138.

SChNitzler M, Petereit F AND NAhrstedt A. 2007. Transaconitic acid, glucosylflavones and hydroxycinnamoyltartaric acids from the leaves of Echinodorus grandiflorus ssp. aureus, a Brazilian medicinal plant. Braz J Pharmacog 17: 149-154.

TANAKA CMA, SARRAGIOTTO MH, ZUKERMAN-SCHPECTOR J AND MARSAIOLI AJ 1997. A cembrane from Echinodorus grandiflorus. Phytochemistry 44: 1547-1549.

Tressl R, WondraK GT, Garbe LA, KRÜGER RP AND REWICKI D. 1998. Pentoses and hexoses as sources of new melanoidin-like Maillard polymers. J Agr Food Chem 46: 1765-1776.

VAN BOEKEL MAJS. 2006. Formation of flavour compounds in the Maillard reaction. Biotechnol Adv 24: 230-233.

Vidal LS, Alves AM, Kuster RM, LAGE C AND Leitão AC. 2010. Genotoxicity and mutagenicity of Echinodorus macrophyllus (chapéu-de-couro) extracts. Genet Mol Biology 33: 549-557. 
